\title{
Utilisation of inorganic and organic soil phosphorus in a hill country soil
}

\author{
K.W. PERROTT \\ AgResearch, Ruakura Agricultural Centre, Private Bag 3123, Hamilton, New Zealand
}

\begin{abstract}
Changes in phosphorus (P) fractions of unfertilised and fertilised (superphosphate) soil were investigated over five years at a hill country site near Te Kuiti. Only soil inorganic P $(\mathrm{Pi})$ reserves were utilised for plant uptake when superphosphate was withheld at the site. Immobilisation of $\mathrm{P}$ as soil organic $\mathrm{P}(\mathrm{P} 0)$ contributed to depletion of the soil $\mathrm{Pi}$ reserves during the first two years of this trial. Where superphosphate was applied, immobilisation of $\mathrm{P}$ as $\mathrm{Po}$ amounted to about $25 \%$ of applied $\mathrm{P}$ during the five years measurements were made. Changes in soil $\mathrm{P}$ fractions indicated that all forms of soil $\mathrm{Pi}$ were utilised when superphosphate was withheld. These included readily available $\mathrm{Pi}, \mathrm{Al}$ $\mathrm{Pi}, \mathrm{Fe}-\mathrm{Pi}$, and residual phosphate rock from previous fertiliser applications. Depletion of the phosphate rock residues in the soil also occurred where superphosphate was applied and appears to have been completed within about two years. The phosphate rock residues had probably accumulated because of the relatively high amounts of unacidulated phosphate rock in superphosphate manufactured before 1983. Accumulation of Po associated with humic acid, or adsorbed on surfaces of hy drous oxides of $\mathrm{Al}$ and $\mathrm{Fe}$, occurred in both fertilised and unfertilised soils. The more labile forms of Po also increased in the fertilised soil.
\end{abstract}

Keywords inorganic phosphorus, organic phosphorus, phosphorus immobilisation, soil phosphorus, soil phosphorus fractions, soil phosphorus utilisation.

\section{Introduction}

Fertiliser use by New Zealand agriculture in the late 1980s was 50 to $60 \%$ below that in the late 1970s (Taylor et al. 1989). The consequent decline in soil fertility was particularly evident in hill country farms. Significant decreases in animal and pasture production occurred on hill country pastures where fertiliser was withheld (Gillingham et al. 1990; Lambert et al. 1990; O'Connor et al. 1990). In this situation, nutrient reserves accumulated from past fertiliser applications determined soil fertility and pasture production.
Fertiliser application (mostly superphosphate), together with biological fixation of nitrogen by legumes, has encouraged the buildup of organic matter in New Zealand pastoral soils. Phosphorus $(\mathrm{P})$ has accumulated in both inorganic (Pi) and organic (Po) forms (Perrott $\boldsymbol{e t}$ al. 1989). Po amounts to $30.80 \%$ of total $\mathrm{P}$ in New Zealandpastoralsoils (Perrott and Sarathchandra 1987).

As these $\mathrm{P}$ reserves determine soil $\mathrm{P}$ status when fertiliser is withheld, the extent to which the different $P$ forms are utilised is important. This paper reports the effects of plus and minus fertiliser treatments on changes in soil $\mathrm{P}$ fractions and the utilisation of soil Pi and Po at a hill country site near Te Kuiti.

\section{Materials and methods}

A small plot trial was established on two paddocks that were part of the nil fertiliser treatment in an animal grazing experiment (O'Connor et al. 1990) at the $\mathbf{A g R e}$ search, Te Kuiti Research Area, $20 \mathrm{~km}$ south of Te Kuiti.

The soil was a Mahoenui silt loam. a central yellowbrown earth (Typic Dystrochrept) typical of 1.3 million ha of North Island hill country. A thin veneer of volcanic ash was present in the surface layer of this soil. Samples (O-75 mm) taken at the first sampling in August 1983 had a med-high Pretention (68\%) and a mean Olsen $\mathrm{P}$ of 14. The $0-30 \mathrm{~mm}$ and $0-75 \mathrm{~mm}$ depths had average bulk densities of 0.54 and $0.66 \mathrm{~g} / \mathrm{cm}^{3}$ respectively. Superphosphate had been applied (average rate $250 \mathrm{~kg} / \mathrm{ha}$ / year) for at least 10 years before the animal grazing experiment whichbegan in April 1983. The pasture was grazed by a flock of sheep (stocking rate 14 ewes/ha) restricted to these and four other paddocks that received no fertiliser.

Six control and six fertilised (250 kg superphosphate/ ha/year) paired plots were established in each paddock. Super-phosphate was applied to the fertilised plots immediately after the first soil sampling in August 1984 and in September 1985, 1986, 1987, and 1988. Pasture production was determined for each plot by a trim cage technique and herbage samples from each cut were analysed for $\mathrm{P}$.

Long term fertiliser effects were investigated with soil samples taken to $30 \mathrm{~mm}$ depth (15 cores $25 \mathrm{~mm}$ dia) at approximately three monthly intervals from August 1984 to June 1989. Samples were also taken to $75 \mathrm{~mm}$ depth at 4- to 7-weekly periods from August 1984 to 
December 1986 as part of a separate study (Perrott et al. 1992) and these were analysed for Pi and Po. After air drying the soil samples were sieved $(<2 \mathrm{~mm})$ to remove roots and plant debris. They were then further ground and sieved $(<150 \mu \mathrm{m})$.

With the O-75 mm samples, Pi was determined by extraction with $0.5 \mathrm{M} \mathrm{H}_{2} \mathrm{SO}_{4}$ (almost equal to total $\mathrm{Pi}$ in this soil) and total Po by ignition (Saunders and Williams 1955; Blakemore et al. 1972). A sequential extractionprocedure (Perrott et al. 1989) was used to fractionate $\mathrm{Pi}$ and $\mathrm{Po}$ in the $\mathrm{O}-30 \mathrm{~mm}$ samples. This involved extraction of soil $\mathrm{Pi}$ and $\mathrm{Po}$ with $0.5 \mathrm{M} \mathrm{NaHCO}_{3}(\mathrm{pH}=8.5)$, followed by $0.1 \mathrm{M} \mathrm{NaOH}$ and then $1.0 \mathrm{M} \mathrm{NaOH}$. Remaining Pi was extracted with $0.5 \mathrm{M} \mathrm{H}_{2} \mathrm{SO}_{4}$. Residual Po was then determined after ignition $\left(550^{\circ} \mathrm{C}\right)$ and extraction with $0.5 \mathrm{MH}_{2} \mathrm{SO}_{4}$. Topreventprecipitationof $\mathrm{Ca}-\mathrm{Pi}$ and $\mathrm{Ca}-\mathrm{Po}$ compounds in the alkaline extracts (Perrott 1992). exchangeable Ca was removed from the soil samples before the sequential extractions by washing with $1 \mathrm{MNaCl}$.

\section{Data analysis}

Differences between fertilised and unfertilised plots were tested by analysis of variance at each sampling date. Rates of change of total $\mathrm{P}$ and the different $\mathrm{P}$ fractions for each plot were calculated using regression analysis against time (August 1984 - August 1986 for 075 mm samples and August 1984 - June 1989 for 0-30 $\mathrm{mm}$ samples). Means and standard errors of means (SEM) were then calculated for unfertilised and fertilised soil.

\section{Results and discussion}

Pasture production and $P$ uptake

Withholding fertiliser reduced pasture production slightly in the first year of the trial, but there were reductions of approximately $20 \%$ in subsequent years (Table 1 ). The decline in $\mathrm{P}$ uptake was more marked, ranging from approximately $20 \%$ reduction in the first year to ap proximately $40 \%$ in the fifth year. Pasture composition was also influenced by withholding fertiliser, with a decline in white clover content and an increase in moss and weeds (O'Connor et al. 1990).

\section{Total P, total Pi and total Po}

The changes in soil Pi and Po with time $(0-30 \mathrm{~mm}, 1984$ 1989)arepresentedinFigs. 1 and 2. Table 2 summarises the original levels of $\mathrm{Pi}, \mathrm{Po}$ and total $\mathrm{P}$, and their rates of change with time, for both time periods using units of $\mathrm{kg}$ P/ha in the O-75 mm depth. Data for the 1984-1989 period were estimated from the $\mathrm{O}-30 \mathrm{~mm}$ samples using
Table 1 Effect of withholding fertiliser on pasture production and $\mathbf{P}$ uptake

\begin{tabular}{lcccc}
\hline \multirow{2}{*}{ Year } & Unfertilised & Fertilised & SED & \%decline \\
\cline { 2 - 4 } & \multicolumn{4}{c}{ Pasture production (kg DMhayear) } \\
\hline $84 / 85$ & 6220 & 6630 & 343 & 6 \\
$85 / 86$ & 7300 & 9100 & 445 & 20 \\
$86 / 87$ & 7460 & 9960 & 450 & 25 \\
$87 / 88$ & 8720 & 10710 & 497 & 19 \\
$88 / 89$ & 7010 & 8700 & 351 & 19 \\
\hline \multicolumn{5}{c}{ P uptake (kg P/ha/year) } \\
\hline $84 / 85$ & 13.6 & 17.2 & 0.89 & 21 \\
$85 / 86$ & 17.2 & 25.0 & 1.36 & 31 \\
$86 / 87$ & 14.4 & 23.9 & 1.08 & 40 \\
$87 / 88$ & 20.2 & 30.3 & 1.29 & 33 \\
$88 / 89$ & 14.6 & 25.8 & 1.10 & 43 \\
\hline
\end{tabular}

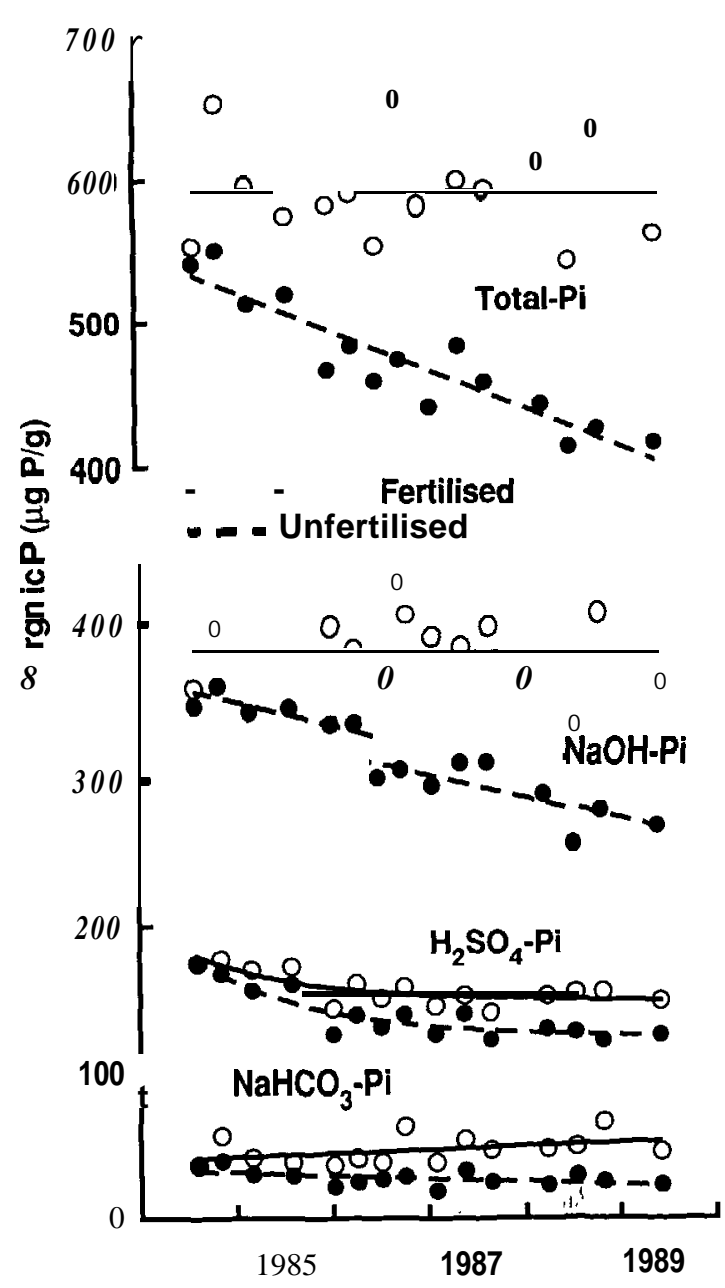

Figure 1 Changes in total soil pi and Pi fracti ons with ti ne $(0.30 \mathrm{~mm}$ samples). closed symbols - unfertilised plots. Open symbols - fertilised plots. Lines are linear firs to data except for $\mathrm{H}_{2} \mathrm{SO}_{4}-\mathrm{Pi}$ where an exponential fit was used. 


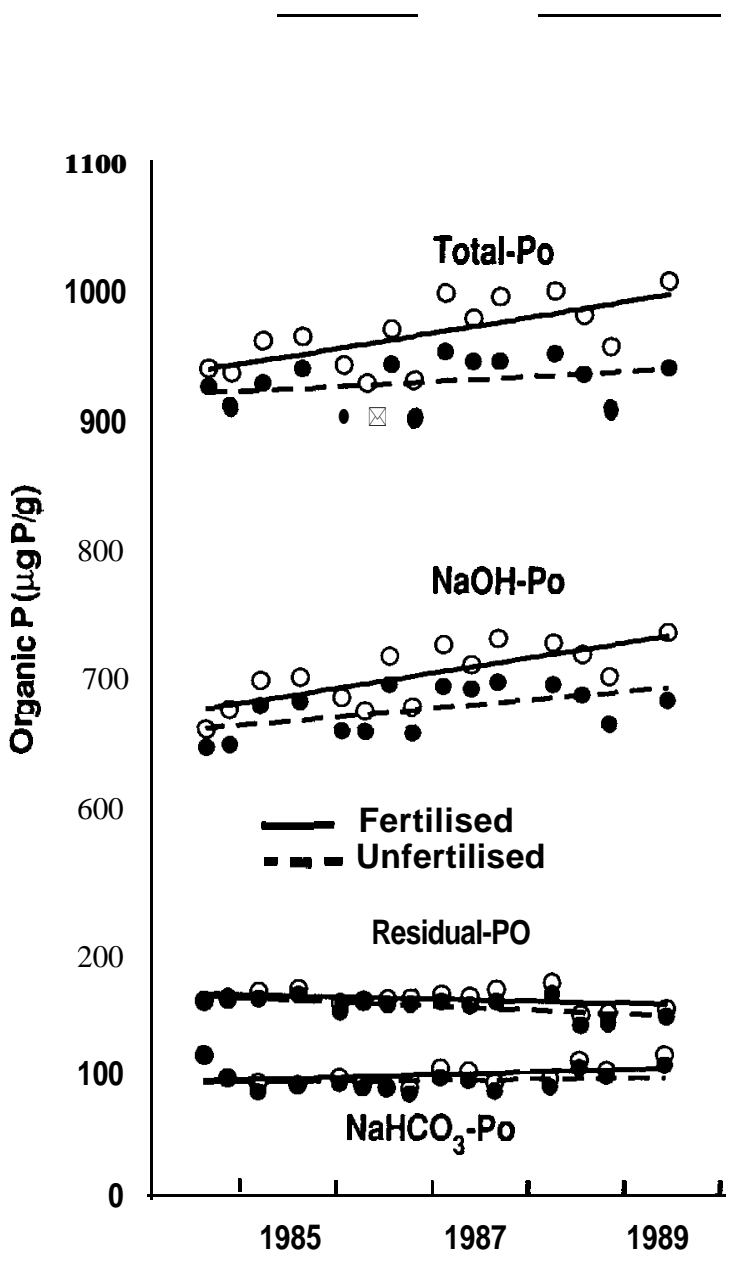

Figure. 2. Changes in total soil $P 0$ and Bo fractions with time $(0-30 \mathrm{~mm}$ samples). See Fig.1 far explanation of symbols. Lines are linear fits to data.

Table 2 Estimated rates of change in soil $p$ levels $(\mathrm{kg}$ P/ha/year for $0-75$ mm depth)

\begin{tabular}{|c|c|c|}
\hline \multirow[t]{2}{*}{$\begin{array}{l}\text { Original } \\
\text { level }\end{array}$} & $\begin{array}{l}\text { 1964-1969 estimated } \\
\text { from }\end{array}$ & $\begin{array}{l}\text { 1964-1966 estimated } \\
\text { from }\end{array}$ \\
\hline & $0-30 \mathrm{~mm}$ data $(n=15)$ & $0-7.5 \mathrm{~mm}$ data $\quad(n=19)$ \\
\hline
\end{tabular}

(kg P/ha) Unfertilised Fertilised Unfertilised Fertilised

\begin{tabular}{lccccc}
\hline Total PI & 190 & -9.7 & -0.5 & -12.9 & -9.1 \\
(SEM) & & $(0.67)$ & $(1.21)$ & $\mathbf{( 1 . 8 )}$ & $(2.3)$ \\
Total Po 480 & $\mathbf{+ 2 . 0}$ & $\mathbf{1}$ & $\mathbf{+ 1 2 . 1}$ & $\mathbf{+ 1 0 . 0}$ \\
(SEM) & $(1.06)$ & $\mathbf{( 0 . 8 8 )}$ & $(1.7)$ & $(3.2)$ \\
Total P & 670 & -10.5 & $\mathbf{+ 4 . 6}$ & -0.6 & $\mathbf{+ 1 . 0}$ \\
(SEM) & & $(1.16)$ & $\mathbf{( 2 . 1 )}$ & $(2.23)$ & $(5.07)$ \\
\hline
\end{tabular}

a. Estimated from 0-30 $\mathrm{mm}$ data using mean ratios of $\mathrm{PO}, \mathrm{PI}$ and total $\mathrm{P}$ in 0-75 mm samples to total extractable $\mathrm{P}, \mathrm{PI}$ and total $\mathrm{P}$ in $0-30$ $\mathrm{mm}$ samples for eight sampling dates In 1964-1966. the mean ratios of $\mathrm{Po} . \mathrm{Pi}$ and total $\mathrm{P}$ in the $\mathrm{O}-75 \mathrm{~mm}$ samples to the total extractable Po, Pi and total $\mathrm{P}$ in the corresponding O-30 mm samples (eight sampling dates 1984-1986). This was done because the 0-75 $\mathrm{mm}$ depth is more representative of the rooting zone than is the 0 $30 \mathrm{~mm}$ depth.

There were no significant trends in total $\mathrm{P}$ level of samples taken from either the fertilised or unfertilised plots during 1984-1986 (O-75 mm). However, Pi decreased and Po increased during thii period for both the fertilised and unfertilised plots. During 1984 - 1989 the total $\mathrm{P}$ and total Pi levels $(\mathrm{O}-30 \mathrm{~mm})$ of the unfertilised plots declined. while total $\mathrm{P}$ increased in the fertilised soil. There were no significant trends for total Po in the unfertilised plots or total $\mathrm{Pi}$ in the fertilised plots over the 1984.1989 period.

These changes in soil $\mathrm{P}$ levels indicate that $\mathrm{Pi}$ reserves were the main source of $\mathrm{P}$ for plant uptake when fertiliser was withheld at this site. There was no net utilisation of soil Po. The decline of soil Pi by about 10 $\mathrm{kg} \mathrm{P} /$ ha/year is approximately $\mathbf{5 \%}$ of the total Pi reserves. of $190 \mathrm{~kg} \mathrm{P} / \mathrm{ha}(\mathrm{O}-75 \mathrm{~mm})$. Immobilisation of fertiliser $\mathrm{P}$ as soil $\mathrm{Po}$ in the fertilised plots (about $6.10 \mathrm{~kg} \mathrm{P} / \mathrm{ha} /$ year, O-75 mm) was asignificantcomponent of fertiliser $\mathrm{P}$ application (25 kg P/ha/year). Without fertiliser. significant immobilisation of $\mathrm{P}$ as $\mathrm{Po}$ occurred during the first two years. This would have contributed to the depletion of soil $\mathrm{Pi}$ reserves.

Net stock transfer of $\mathrm{P}$ away from the plots (the rest of the paddock was not fertilised). and immobilisationof $\mathrm{P}$ as soil Po. can explain the failure of $\mathrm{Pi}$ to increase in the fertilised soil. Because the fertilised plots were inside unfertilised paddocks all the net pasture uptake of $\mathrm{P}$ due to fertiliser would have been tranferred by stock. This amounted to about $35 \%$ of applied P (Table 1) and together with the net changes in total soil P (Table 2) accounted for all the $\mathrm{f}$ zrtiliser $\mathrm{P}$ applied. In a situation where the whole paddock was topdressed, net stock transfer would be smaller and soil Pi levels would probably increase.

The relatively low level of soil Pi reserves explain the marked decline in pasture production and $\mathrm{P}$ uptake at this site. Inasimilarstudy Perrottetal. (1990)measured soil Pi reserves of about $960 \mathrm{~kg}$ P/ha $(0-75 \mathrm{~mm})$ at ahighproducing dairy farm on a yellow-brown loam in the Waikato. Pasture production at this site did not decline until seven years after stopping fertiliser when a $8 \%$ decrease was measured. Therate of soil $\mathrm{Pi}$ decline at that time was approximately $24 \mathrm{~kg} \mathrm{P} / \mathrm{ha} /$ year $(\mathrm{O}-75 \mathrm{~mm})$. 
Soil Po levels at the Waikato site were approximately $850 \mathrm{~kg} \mathrm{P} / \mathrm{ha}(\mathrm{O}-75 \mathrm{~mm})$ which was much higher than for the Te Kuiti soil. No significant changes in soil Po with time were observed at the Waikato site, indicating that the soil was at. or near, equilibrium with respect to Po accumulation. In contrast, Po was still accumulating at the Te Kuiti site. Nguyen et al. (1989) also demonstrated accumulation of Po in fertilised and unfertilised soil at an irrigated mid-Canterbury site which had similar Po levels to the Te Kuiti soil. The rate of accumulation of soil Po $(5.8 \mathrm{~kg} \mathrm{P} /$ ha/year) was similar. Apparently, net accumulation of soil Po under pasture is likely until an equilibrium level is attained as has evidently occurred with the Waikato soil . Given the relatively low levels of fertiliser topdressing on hill country farms, it is likely that most hill country pastoral soils are still at a stage where net immobilisation of $\mathrm{P}$ as Po is occurring.

\section{$\mathrm{Pi}$ and $\mathrm{Po}$ fractions}

Phosphate fertiliser effects concentrate in the surface layers of the soil. A O-30 mm sampling depth was therefore chosen to reduce dilution of any fertiliser effects on the soil $\mathrm{P}$ fractions. The sequential extraction procedure used (Perrott $\boldsymbol{e t} \boldsymbol{a l}$. 1989) was designed to separate soil $\mathrm{P}$ into pools of decreasing availability to plants (Hedley et al. 1982). The initial, milder reagents extracted the more labile forms of soil Pi and Po.

Table 3: Rates of change of soil Pi and Po fractions with time $(\mu \mathrm{g} / \mathrm{g} / \mathrm{year}$ for $0-30 \mathrm{~mm}$ depth)

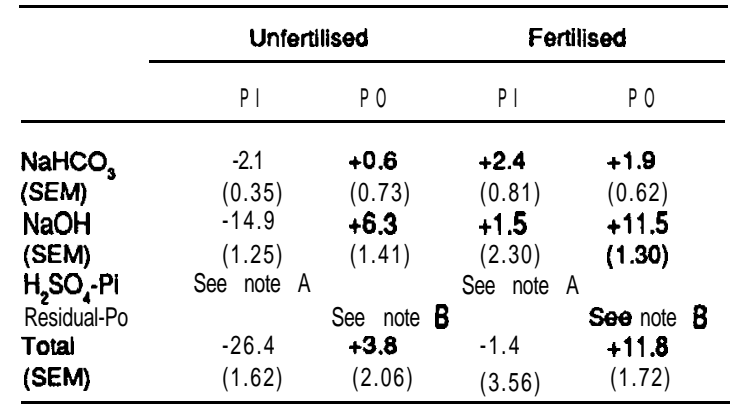

A. See Flg. 1. A significant decline occurs over first two years

B. See Fig. 2. No significant change occurs In first four years.

Amounts of each soil $\mathrm{P}$ fraction are presented for each sampling time in Figs. 1 and 2. The $0.1 \mathrm{M} \mathrm{NaOH}$ and $1.0 \mathrm{M} \mathrm{NaOH}$ fractions have been combined. Table 3 summarises trends in the change of soil $\mathrm{P}$ fractions with time.

In the unfertilised soil, all the Pi fractions declined significantly with time (by about $4 \cdot 6 \%$ per year) indicating utilisation of all forms of soil $\mathrm{Pi}$ - readily available $\left(\mathrm{NaHCO}_{\mathbf{3}}-\mathbf{P i}\right)$, less available forms of $\mathrm{Al}-\mathrm{Pi}$ and $\mathrm{Fe}-\mathrm{Pi}(\mathrm{NaOH}-\mathrm{Pi})$ and apatite $\mathrm{P}\left(\mathrm{H}_{2} \mathrm{SO}_{4}-\mathrm{Pi}\right)$. However, most of the decline in $\mathbf{H}_{2} \mathbf{S O}_{4}-\mathbf{P i}$ occurred in the first two years (Fig. 1). This probably represents dissolution of unacidulated phosphate rock accumulated from previous superphosphate topdressing.

A similar net dissolution of accumulated phosphate rock residues also appeared to occur in the fertiliied soil despite addition of some unacidulated phosphate rock in current superphosphate applications. This probably resulted from higher than normal amounts of unacidulated phosphate rock in New Zealand superphosphate manufactured between 1970 and 1983 (Edmeades et al. 1990). Increasing amounts of $\mathrm{NaHCO}_{3}-\mathrm{Pi}$ reflected superphosphate addition but there was no significant trend for $\mathrm{NaOH}-\mathrm{Pi}$. Annual application of soluble $\mathrm{P}$, which is adsorbed by hydrous $\mathrm{Al}$ and $\mathrm{Fe}$ oxides, increased the variability of the $\mathrm{NaHCO}_{3}-\mathrm{Pi}$ and $\mathrm{NaOH}-\mathrm{Pi}$ measurements.

The last three sampling dates strongly effected the regression analysis for residual Po which included the most recalcitrant forms of soil Po. However, no significant trends occurred over the first four years (Fig. 2). Po associated with humic acid or adsorbed by hydrous oxides of $\mathrm{Al}$ and $\mathrm{Fe}(\mathrm{NaOH}-\mathrm{Po})$ increased significantly with time in both the unfertilised and fertilised soils. There was also a smaller, but significant, increase of the more labile soil Po $\left(\mathrm{NaHCO}_{\mathbf{3}}-\mathrm{Po}\right)$ in the fertilised soil.

While there was no net utilisation of soil Po at this site, mineraliiation of the more labile Po compounds could still have occurred. Input of labile Po compounds from plant roots and soil micro-organisms may have replaced losses due to mineralisation. Accumulation of soil Po probably occurs as compounds like phytates that are not mineralised when adsorbed by soil surfaces.

\section{Conclusions}

Withholding fertiliser at this site caused depletion of the soil Pi reserves by about $10 \mathrm{~kg} \mathrm{P} / \mathrm{ha} /$ year $(\mathrm{O}-75 \mathrm{~mm})$ equivalent to $5 \%$ of total $\mathrm{Pi}$ reserves at this depth. The depleted reserves included readily available $\mathrm{Pi}, \mathrm{Pi}$ associated with soil $\mathrm{Al}$ and $\mathrm{Fe}$, and unacidulated phosphate rock accumulated from past superphosphate applications. No net depletion of soil Po occurred. In the fertiliscd soil approximately $25 \%$ of applied $\mathrm{P}$ was immobilised as soil PO. Accumulation of soil PO also occurred with unfertilised soils during the first two years of the trial.

The low Pi reserves and net accumulation of Po is probably common to most hill country pastoral soils because of past fcrtiliser history. Consequently, continued inputs of fertiliser $\mathrm{P}$ are required on these soils to maintain exisiting Pi reserves and prevent production declines. 


\section{ACKNOWLEDGMENTS}

I am grateful to R.A. Littler for assistance with trial design, C.E. Smart and K.R. Jones for assistance in trial management and sampling, Fiona M. Maher, Cherie Ramsbotham. Delwyn Jenkins and D. Phizacklea for technical assistance, and Barbara Dow for statistical analyses.

\section{REFERENCES}

Blakemore, L.C.; Searle, P.L.; Daly. B.K. 1972. Methods for analysis of soils. NZ Soil Bureau Report $10 \mathrm{a}$.

Edmeades, D.C.; Sinclair, A.G.; Feyter, C.; Brown, M.W.; Rajan, S.S.S. 1990. The citric acid test for available $\mathrm{P}$ in superphosphate - A review. Proceedings of the New Zealand Fertiliser Manufacturers' Research Association Conference: $262-292$

Gillingham, A.G.; Richardson, S.; Power, I.L.; Riley, J. 1990. Long term effects of withholding phosphate application on North Island hill country: Whatawhata Research Centre. Proceedings of the New Zealand Grassland Association 51: 1116.

Hedley, M.J.; Stewart, J.W.B.; Chauhan, B.S. 1982. Plant induced changes in therhizosphere of rape (Brassica napus var. Emerald). III. Changes in L-value, soil phosphate fractions and phosphatase activity. New phytologist 91: 45-56.

Lambert, M.G.; Clark, D.A.; Mackay, A.D. 1990. Long term effects of withholding phosphate application on North Island hill country: Ballantrae. Proceedings of the New Zealand Grassland Association 51: 25-28.

Nguyen, M.L.; Rickard, D.S.; McBride, S.D. 1989. Pasture production and changes in phosphorus and sulphur status in irrigated pastures receiving long-term applications of superphosphate fertiliser. New Zealand journal of agricultural research 32: 245-262.
O'Connor,M.B.; Smart, C.E.; Ledgard, S.F. 1990 . Long term effects of withholding phosphate application on North Island hill country: Te Kuiti. Proceedings of the New Zealand Grassland Association 51: 21-24.

Perrott. K.W. 1992. Effect of exchangeable calcium on fractionation of inorganic and organic soil phosphorus. Communications in soil science and plant analysis 23: 827-840.

Perrott, K.W.; Maher, F.M.; Thorrold,B.S. 1989. Accumulation of phosphorus fractions in yellowbrown pumice soils with development. New Zealand journal of agricultural research $32: 53$ 62.

Perrott, K.W.; Sarathchandra. S.U. 1987. Nutrient and organic matter levels in a range of New Zealand soils under established pasture. New Zealand journal of agricultural research 30: 249-259.

Perrott. K.W.; Sarathchandra. S.U.; Waller, J.E. 1990. Seasonal storage and release of phosphorus and potassium by organic matter and the microbial biomass in a high-producing pastoral soil. Australian journal of soil research 28: 593-608.

Perrott, K.W.; Sarathchandra, S.U.; Dow, B.W. 1992. Seasonal and fertiliser effects on the organic cycle and microbial biomass in a hill country soil under pasture. Australian journal of soil research 30: 383-394.

Saunders, W.M.H.; Williams, E.G. 1955. Observations on the determination of total organic phosphorus in soils. Journal of soil science 6: 254-267.

Taylor, N.W. 1989. A review of current financial trends and farm incomes in the New Zealand sheep and beef industry. NZ Meat and Wool Board Economic Service. Paper G 1986.23 pp. 